\title{
Islam, Slave Agency and Abolitionism in the Middle East and North Africa
}

Western understanding of the institution of slavery and the experience of slave themselves has, in general, been defined and dominated by a template drawn from the modern plantation slavery of the Americas. ${ }^{1}$ Images of slave agency and of abolitionism have been derived from the same template in which slave agency is equated with unambiguous resistance to slavery as such, and abolitionism attributed to a moral response originating within the slaveowning society and possessing a strong redemptive dimension. ${ }^{2}$ The domination of this historically very specific template has often seemed to eclipse all other forms of slavery, even that of classical antiquity, because of the sheer scale of Atlantic slavery, its historical significance in the birth of the modern world in general and of capitalism in particular, its creation throughout the Americas and subsequently in Europe of numerically substantial and politically significant black diaspora communities, the role of abolition in imperial and national, especially British, mythology, and perhaps also to the reach of the US media.

The prevalence of this template, derived from the experience of Atlantic slavery and Western abolitionism, has tended to produce a distorting effect on attempts to understand slavery in the Middle East and North Africa, especially concerning the emergence of a discourse of abolitionism. Resulting perceptions have been reinforced by an 'Orientalist' inclination to view the Islamic world as absolutely sui generis. Slavery in the Middle East and North Africa has almost always, and uniquely, been situated, not within a geographical or chronological context, but within an ideological, Islamic, framework. ${ }^{3}$ Defined as Muslim, these societies, unredeemed by abolitionism, are thus rendered vulnerable, their apparent failure to develop any sustained self-criticism in respect to slavery a reflection of a profound civilizational dysfunction

Yet the significant historical rupture in the operation of the institution of slavery in the early modern period was not in fact religious or civilizational, between the Islamic Middle East and Christian Europe, but economic, arising from Iberian expansion into the Americas from the sixteenth century, the development of commercial plantations in the colonies of the New World eventually resulting in a novel super-exploitation of slave labour and an overtly racialized discourse absent from older systems on either side of the Mediterranean. Despite the common ascription of a uniquely 'Islamic' character to Middle Eastern and North African 
slavery, the institution shares its key characteristics with practices and notions common to medieval and early modern southern Europe, with which countries it also shares an absence of hegemonic abolitionism. Across both the Middle East and North Africa, the relative weakness of abolitionist sentiment can best be explained not by the power of an Islamic discourse but by the structures of slavery in the region and especially the specific forms of agency to which those structures gave rise. In the Middle East and North Africa neither widespread slave violence, individual or collective, nor the fear of it, pervaded society. With the exception of the medieval Zanj revolt, Middle Eastern and North African societies suffered no trauma resulting from slave resistance. Local elites, and slave holders in particular, were spared the dramatic moments of challenge experienced by their counterparts in the Americas, abolitionism emerging slowly as slavery itself withered away. Yet, if abolitionism among literate elites indeed often remained a marginal issue, it was of greater immediate relevance to the lower classes across the region who often gave evidence of their fear and hatred for the practice, showed sympathy for and even solidarity with ill-treated slaves, and, by the early twentieth century, began to integrate opposition to slavery within a new political consciousness.

An historically accurate appreciation of the practice and ideology of slavery in the Middle East and North Africa is of more than theoretical importance. Until recently, slavery in the Middle East and North Africa was seen as an institution belonging essentially to the premodern world, surviving into the nineteenth and twentieth century only as a residue, a relic of rapidly declining significance. Yet a changing modern consciousness is increasingly highlighting the continuing relevance of slavery and its legacies in shaping Middle Eastern societies. Firstly, it should be noted that legal slavery continued to exist on the margins of the region until very recently. Even in Iran formal abolition took place only in 1928, while slavery continued its legal existence in Saudi Arabia until 1962, in Oman until 1970 and in Mauretania until 1981. Indeed the first workers in the Qatari oil industry, in the late 1940searly 1950s were slaves, their owners appropriating up to ninety per cent of their salaries. ${ }^{4}$ It seems, furthermore, frequently to have survived legal abolition, forms of domestic dependence and servitude continuing, on the margins of the Middle East until the twenty-first century, hardly distinguishable from past slavery. ${ }^{5}$ A generalized amnesia regarding black slavery across the Middle East has been blamed for the social invisibility and marginalization of black communities, including Afro-Arabs, Afro-Turks and Afro-Iranians, while the contribution of black African slaves to the cultures of various Middle Eastern societies 
remains largely unrecognized. The legacy of slavery may even be perceived as nestling within hegemonic concepts of political authority and authoritarianism. ${ }^{6}$

There are more sinister developments. An alleged revival of slavery during the recent civil war in the Sudan excited extensive publicity in the West, much of it, especially its anti- 'Arab' diatribes, rehearsing a script reminiscent of nineteenth century European abolitionism. The recent and startling resurrection and rehabilitation of an imagined Islamic discourse on slavery has also become of central importance to radical Islamist groups such as Islamic State in the Middle East and Boko Haram in West Africa, a feature of their struggle with Islamic modernism, this imagined discourse sharing many of its fundamental premises on the primacy and historically immutable role of Islam with Western Orientalism. At the same time, this lurid pseudo-Islamist discourse has both itself arisen from, and reinforced, the crudest Western fantasies deriving from exoticized notions of female harem slavery in the Middle East.

In understanding slavery in the Middle East and North Africa, a template drawn from the modern plantation slavery of the Americas is of most use for the contrast which it provides. The Americas between the sixteenth and the nineteenth centuries, like ancient Greece and Rome, were slave societies, slave labour the foundation of the economic system. Middle Eastern societies were, on the contrary, societies with slaves, slave labour, although utilized in a variety of roles, only exceptionally the basis of productive activity. The type of slavery which became predominant in North and South America and the Caribbean was an entirely new and modern invention. Quickly becoming divorced from its Mediterranean origins, it developed into a system which possessed a quite novel scale, ferocity, and exploitative capacity. ${ }^{7}$ Vast numbers of Africans were transported, not into the European imperial metropolises, but into their American colonies, where they often outnumbered whites. There they were organized into work gangs on plantations producing for the European market and generating the enormous profits which became the foundation for the emergence of an entirely new economic system, that of industrial capitalism. It was, furthermore, a fully racialized system. The condition of slavery was indelibly and essentially connected to blackness. ${ }^{8}$ They invariably occupied the most degraded and highly stigmatized social positions, and both they and their children could expect to die in slavery. Slaves in the Americas deployed the full range of strategies available to them in their struggle for survival, including collaboration and the 'weapons of the weak'. But the system of slavery itself, 
which on the one hand brought them together in large numbers and encouraged a collective consciousness through the field gang and the barracks, and on the other hand offered few hopes for amelioration or release, lent itself to marronage and slave revolt. The rapid political changes of the late eighteenth century opened up an ideological space in which slaves themselves could conceptualize their freedom and made slave-owning increasingly unpalatable to a new, democratically-inclined public opinion in Europe. In the story of slavery in the Americas, the archetypal slave hero, a man, offers an ideological and political challenge to the system itself, complementing the efforts of his allies among white reformers. In this story the figure of Toussaint Louverture looms large.

The operation of the institution of slavery in the Middle East and North Africa presents a very different picture. Slavery had existed across the Middle East and North Africa from the earliest times. The rise of Islam in the seventh century provided a new legal framework but the actual practice of slavery continued to be heavily influenced by pre-existing patterns. Elite slavery, although absent during the egalitarianism of the early years of Islam, reappeared under the Abbasid empire, demonstrating features familiar from pre-Islamic imperial practices in the region including those of the Persians and Romans. It continued in the Mamluk states which ruled most of the Middle East in the medieval period, reaching its fullest development in the Ottoman empire. Muslim rulers, often of slave origin themselves, staffed their armies and bureaucracies with slaves, female slaves entered elite harems, becoming wives and mothers of high officials and even sultans, and eunuchs occupied key positions of particular trust and influence. ${ }^{9}$ Slavery, however, as it persisted across the Middle East and North Africa until the twentieth century and even beyond, was almost indescribably various and differentiated and elite slavery, despite the attention it has received, was not typical of the slave experience. In the Middle East and North Africa, no hegemonic indigenous elite abolitionist discourse manufactured a trove of captivity narratives or moulded the various types of local slavery into a representative experience. Even recent scholarship, given the diversity of Middle Eastern slavery and the absence of collective action sufficiently significant to leave archival traces or popular memory, has produced rather a proliferation of microhistories, stories of particular slaves located within specific historical contexts, incapable, either individually or cumulatively, of representing the slave experience. $^{10}$ 
Across the region, the majority of slaves led lives far from luxury and power. Nonetheless, the roles available to them, especially if they were male, often offered some opportunities for advancement while the real possibility of manumission encouraged cooperation with the system at all levels. Female slavery was largely domestic and sexual but even with such limited scope, women might devise strategies to improve their position. ${ }^{11}$ Both male and female slavery of this kind was considered to be, and often actually was, temporary, and usually framed as some sort of subordinate incorporation into a household, family or lineage. Inevitably, however, slaves at the bottom of the pile might be, if female, used for prostitution, and if male, condemned to the harsh conditions of agricultural production, mining, pearling or the galleys. In all these occupations, however, they toiled alongside and in the same conditions as free people. Slaves were found in a variety of social positions. Often items of conspicuous consumption rather than production, slaves might function as very visible signifiers of the wealth and power of their owners. Indeed slaves had their own shadow hierarchies, dependent upon and reflecting the status of their owners, these hierarchies complicated by gender and sometimes by race. The custom of segregation and confinement of usually 'white' elite women, free wives and slave concubines, was maintained through the authority of black male slaves, the eunuchs. Slavery was not essentially racialized. It was associated primarily not with colour but with unbelief, $k u f r$, and slaves might be black or white, with black slaves sometimes occupying positions of authority over both white slaves and free white people. The quotidian operation of the institution of slavery in the Middle East and North Africa, although theoretically subject to supposedly unchanging Islamic ordinances, was in fact profoundly determined by the wider political context. By the nineteenth century, as the pace of change accelerated, the institution was becoming increasingly attenuated. Male slavery was in particular declining, and slavery taking on more and more of a feminized character. ${ }^{12}$ Nonetheless, it continued to constitute a bedrock of an elite way of life and no strong, let alone hegemonic, abolitionist sentiment emerged among local elites.

Slavery in the Middle East and North Africa clearly differed in almost every respect from the institution in the modern Americas. Yet to use the comparison to highlight difference does not imply the assumption of the existence of a unique 'Islamic' slavery which has persisted in its essential aspects throughout all historical periods and across the diverse cultural, political and economic environments of the Muslim world. On the contrary, pre-modern Middle Eastern and North African slavery emerges from this comparison not as sui generis but rather 
as possessing deep and pervasive similarities with other contemporary systems, especially those which prevailed amongst its near neighbours on the western coasts of the Mediterranean. In terms of the main features of the institution and the lives led by slaves, medieval and early modern Middle Eastern societies remained close to the traditions and customs which they shared with other Mediterranean countries, especially Italy, Spain and Portugal, and which had common antecedents in the world of ancient Rome, with no visible binary division between Christian Europe and the Islamic Middle East.

As in the Middle East and North Africa, so to in southern Europe, where economic activity was pre-capitalist, slavery was largely domestic, urban and temporary, the enslaved populations of diverse origins and only ever a small, sometimes tiny, proportion of the total population. Regulations in both regions defining and regulating slavery were derived from similar sources, a synthesis of Roman law and Christian Church law (the Byzantine Justinian Code), and their assimilation included the incorporation of prevailing local customs. Constant contact, both peaceful and hostile, between Christian and Muslim states, especially in the Iberian peninsula, contributed to producing alignments in both attitudes to and practices of slavery.

Certainly slavery in the Middle East and North Africa was ostensibly regulated according to Islamic law, a legal framework derived from the Quran and hadith as interpreted by religious scholars. Two questions arise. Firstly, to what extent does the existence of this legal framework justify speaking of a distinctive Islamic form of slavery? Secondly, while the existence of a legal framework, albeit a hybrid derived from a multiplicity of influences, certainly provided ideological and practical guidance for regulating slavery, in what ways and to what extent did the actual practice of slavery conform to, or differ from, the norms enshrined in this framework and what role did legal prescription play in constraining the options regarding slavery available to the authorities?

Unsurprisingly, given their common origins, Islamic arguments for slavery's legal and religious legitimacy bore a striking resemblance to those of the Christian states of the Western Mediterranean. This can be illustrated by a comparison of the consensus of the main features of Islamic law concerning slavery with the provisions of the Siete Partidas, a legal codification compiled in Castile in the thirteenth century. ${ }^{13}$ Both made a presumption that the natural condition of mankind was freedom and that proof of the legitimacy of enslavement 
was required. Both laid down firm regulations regarding who might be enslaved. Neither legal codification defined liability to enslavement by nationality, race or colour. It was unbelief which provoked vulnerability to enslavement. For both, captivity of unbelievers in a just war or jihad was the main legitimate source of slaves. In Islam, free and freed Muslims might not be enslaved under any circumstances, although conversion once enslaved did not bring manumission, and Jews and Christians (dhimmis) who were deemed to have entered into a contract with Islamic rulers and paid special taxes were free from the threat of enslavement. For the Siete Partidas the capture of prisoners, especially non-Christians, in just wars was also a primary condition justifying enslavement.

Both codifications provided certain rights to slaves and offered a number of legal mechanisms for manumission. The Quran urged kindness to the slave, recommended manumission and that masters allow slaves to earn or purchase their freedom through legally enforceable contractual arrangements. The slave was entitled to seek a formal contract with the owner to purchase eventual manumission and the right to adequate food, clothing and lodging. Any cruel treatment allowed the slave to seek redress through the courts, manumission or a new master. A female slave who bore her master a child gained the status of umm al-walad, her child was free, her own chattel condition was partially lifted and she was entitled to freedom on her owner's death. The prostitution of slaves was illegal. The slave had certain rights of ownership although he could not own a slave, and had the right to marry but with the owner's approval. The similarities to the Siete Partidas are striking. Here too owners were not allowed to treat their slaves with cruelty, to inflict excessive physical punishment, to separate families or to exploit them sexually and slaves were entitled to marry with their owner's permission. Slaves were permitted to obtain outside employment and to own property and to purchase their freedom and to seek legal redress through court proceedings if their owners flouted these conditions.

As well as common Roman and Byzantine legal origins, slavery in both the Middle East and southern Europe demonstrated strikingly similar broader ideological and religious underpinnings. Both Christianity and Islam advanced a conceptualization of ideal human unity, but both also introduced a crucial practical dualism between believers and nonbelievers, an echo of Aristotle's idea of 'natural slaves,' whom the Greeks had equated with Barbarians. For both Muslims and Christians, slavery was a result of sin or kufr while metaphors of slavery as submission to God survived in both Christian and Islamic theology. ${ }^{14}$ 
Both Christianity and Islam relied on Biblical stories to justify enslavement, particularly Noah's curse on the 'sons of Ham,' believed to refer to black Africans, and their consignment to slavery. ${ }^{15}$

Medieval and early modern southern Europe and the Middle East and North Africa possessed both black and white and Christian and Muslim slaves. For both Muslims and Christians, slavery was closely associated with the just war, the crusade or jihad. During the Iberian Reconquista, for example, both Muslim and Christian frontier states raided and enslaved with complete political and theological legitimacy, the number of Muslim slaves held by Christian states increasing with their military successes. Neither Islam not Christianity defined slavery through colour yet, in both societies, blackness was generally stigmatized and possessed residual connotations of slave status. Not only the legal and ideological but also the practical day to day operations of the institutions of slavery in the Middle East and southern Europe were remarkably similar. One study of black slaves and freedmen in fifteenth and sixteenth century Portugal, for instance, illustrates extraordinary parallels with the Middle East in terms of legal and philosophical justifications, the daily lives of slaves, their occupations, their relationship with the legal system, with religious institutions, with the white majority, the possibility of manumission and the consequences of flight. ${ }^{16}$

The similarities between pre-modern European and Middle Eastern slavery undermines the notion of an essentialist binary difference. The application of the designation 'Islamic' to systems of slavery in the Middle East and North Africa may be problematized further by contrasting the legal framework which supposedly provided ideological and practical guidance for regulating slavery with the actual policies devised and enforced by the temporal power.

Relations between the ulama, as interpreters of Islamic legal prescriptions, and rulers and their elites, driven by secular political, military and domestic considerations, seem to have been subject to perennial tensions. In relation to slavery, and indeed in general, where the needs of the state and the opinions of the ulama collided, it was the secular authority which usually triumphed. In general the ulama constituted a conservative force. Drawn from the same social strata as slave owners and often slave owners themselves, their sympathies lay with the defence of private property, including property in slaves, although they were also professionally committed to ensuring that slavery did not exceed the bounds of the law. Yet 
as a recent discussion of Sultan Mawlay Ismail's creation of a supposedly slave army in late seventeenth century Morocco shows, slave owning elites and rulers were able and willing to exert strenuous pressure to bend religious opinion should the laws be clearly violated and religious opinion recalcitrant. ${ }^{17}$

Sultan Mawlay Ismail's creation of an army by the enslavement of free blacks and the reenslavement of black ex-slaves vividly illustrates both the state's readiness to disregard the law on exemption from enslavement and the flimsiness of legal protection when confronted by political power. ${ }^{18}$ Islamic opinion was unanimous and forceful on the prohibition of the enslavement of Muslims. Nonetheless, when Sultan Mawlay Ismail embarked on the project of building a new army through which to consolidate his rule, he and his officials forcibly recruited only blacks, choosing them as suitable for enslavement on the grounds of their skin colour and their often wrongly presumed, and never demonstrated, slave origins. Confronted by this gross violation of Islamic precepts, certain members of the ulama demurred. The sultan, aware of the religious untenability of his position and conscious of the need to preserve a semblance of legitimacy for his military project and his rule in general, launched a campaign to persuade the ulama to withdraw their objections. Upon their continuing to refuse to endorse the sultan's actions, Mawlay Ismail responded not by halting the project but by threatening the ulama with fines, imprisonment, torture and death. One scholar was indeed executed while others fled to the mountains. Eventually the sultan succeeded in extracting satisfactory support from those members of the ulama who were recipients of royal patronage. ${ }^{19}$

Another case which aroused unease and divided opinion was the Ottoman devshirme, the periodic levy of male children imposed on the sultan's Balkan Orthodox Christian subjects. Not only did the devshirme appear to be a violation of the pact between the Ottoman authorities and the dhimmis, but it raised the spectre of forced conversion, also unambiguously prohibited by the shariah. ${ }^{20}$ Nonetheless, the levy continued, unimpeded by its doubtful legality, as a highly successful method of elite recruitment into the Ottoman military and bureacracy, until superseded by newer forms of elite recruitment from among the freeborn in the seventeenth century. ${ }^{21}$

The cases of Sultan Mawlay Ismail's army and the devshirme show that Islamic regulatory practices were often either circumvented, manipulated or disregarded, although they 
remained theoretically universally operational. Rendered uncertain by the availability of pliant religious scholars eager for patronage, the apparent protection the law offered was often restricted or nullified by casuistry and pressing political qualifications. Customary attitudes meant that blacks everywhere were perennially vulnerable to enslavement, whatever their religious affiliation, dhimmis might find their contractually protected status doubtful or contested, Shias, and by extension Iranians in general, might be denied Muslim status by Sunni Ottomans, border populations, where any authority, religious or secular, was weak, might be raided and enslaved indiscriminately.

Just as the structures of slavery on both sides of the Mediterranean were similar, but vastly different to those of the early modern and modern Americas, so too were the methods through which slaves attempted to exercise their agency. Mass rebellions, of the kind that became increasingly frequent and menacing in the eighteenth century Americas, and which led directly to abolitionism, were extremely rare in the Middle East, indeed were impossible where the majority of slaves were scattered, attached with varying degrees of emotional commitment to individual households and occupying a wide variety of roles and statuses.

Examples of mass rebellion or violence by slaves on any scale in the Middle East and North Africa remain elusive. But the medieval period can boast of one famous slave revolt, that of the Zanj, black slaves imported into Abbasid Iraq from the east Africa coastlands. ${ }^{22}$ Here the connection between agency, in the form of slave resistance, especially violent resistance, and abolition may be established. As in the modern Americas, the trauma of the revolt, and the enormous loss of life and property, appears to have played a significant role in putting an end to the system of plantation slavery itself.

Lower Iraq under Abbasid rule in the eighth century was the location of sugar, cotton and indigo plantations, organized as commercial enterprises on reclaimed marsh land by local merchants with substantial liquid capital at their disposal. The profitability of this plantation economy, indeed a prefiguration of the later sugar complexes of European colonialism in the New World, was built on the massive exploitation of the Zanj, and their conditions, both their hardships and their collective experiences, were exactly those most suitable for the production of violent mass revolt. The agricultural labour they were obliged to perform was crippling, and their submission was not eased by any prospect of amelioration or manumission. They were organized into huge work gangs, of five hundred to five thousand 
men, there was apparently even one gang of fifteen thousand, and they were isolated in the remote rural region of the Shatt al-Arab, in the Basran hinterland. ${ }^{23}$

The Zanj rebelled three times in the late seventh and eighth centuries, until they were finally suppressed by imperial Abbasid armies, and their revolt has been described as 'the greatest servile insurrection in the history of the Islamic world. ${ }^{24}$ Like other such revolts elsewhere, it aimed at seizing power and alleviating and improving the lives and material conditions of its supporters. Like other such revolts, it was constrained by the ideological limitations of its leadership and the character of the period, and its social organization had no alternative but to mimic that of the surrounding imperial polities, including the replication of slavery. The Zanj themselves were eventually suppressed with great ferocity but, like the plantation revolts of the eighteenth and nineteenth century Americas, their resistance and is accompanying violence dealt a fatal blow to the system of plantation slavery itself. The Zanj revolt drowned plantation slavery in medieval Iraq in blood and the system which produced and shaped the revolt was never to be revived. ${ }^{25}$

With the exception of the Zanj, mass slave rebellion was vanishingly rare in the Middle East and North Africa and evidence of slave agency must be sought elsewhere. As the case of the Zanj demonstrates, slave action aimed at abolishing slavery is historically entirely exceptional, even violent slave revolt rarely offering a challenge to the institution itself. Equating slave agency with ideological opposition and physical resistance to slavery as such writes the real Middle Eastern slave and his or her agency, located within specific historical conditions, out of the picture. Such an equation, in particular, marginalizes the experience of the female slave, whose life was constrained by a double, or, if black, a treble subordination. Chained to the household by children she had borne her owner, with the highly constrained and subordinate position of free women only too visible to her, notions of individual autonomy were practically meaningless for the female slave. Open rebellions were, in any case, even in Atlantic slavery, largely available only to men while females, often with children, always constituted an important, latterly numerically preponderant, component of Middle Eastern slave populations. In contrast to the Americas, Islamic law and Middle Eastern political and social customs offered slaves certain possibilities, even rights, although there was a constant tension between the rights which they possessed, according to the ideology of slavery and guaranteed by the Islamic legal framework, and the actual operation of the system as it was moulded by the interests of elite slave-holders. Elite slaves, naturally 
enough, tended to adopt a strategy of maximizing the opportunities available to them, offering no challenge to the institution but embracing its potential for advancement. Among non-elite slaves too, it is possible to trace personal stories showing how individuals made use of the spaces provided by the system, bargaining within its confines rather than offering a challenge to its existence, in the hope of mitigation and ultimately release.

Elite slavery generally produced collaboration, even exploitation, of the advantages the system offered. Kinless elite slaves, lacking commitments other than to their owner, were presumed to be, and often were, absolutely loyal, their efforts to enhance their own status and wealth entirely contingent upon their success in protecting and advancing the position of their owner. So successful was this bargain in coopting slaves that slaves sometimes rejected the opportunity of personal freedom and clung to their position, sometimes functioned as the system's enforcers and sometimes became the fiercest defenders of the status quo. The Janissaries, for example, originally recruited from the devshirme, became notorious reactionaries, opposing all efforts at sultanic military reform in defence of their own privileges until finally suppressed with considerable violence in 1826. Another group whose status and privilege depended on the maintenance of the system were eunuchs, their physical mutilation and their value to elite households both reducing to nothing the appeal of a life outside slavery. The black eunuchs of the Ottoman palace, for example were both rich and influential until the nineteenth century saw the system and their place in it eroded. ${ }^{26}$ These eunuchs, like their confrères in similarly doomed royal establishments elsewhere, the Xing dynasty court in China an obvious parallel, clung to the remnants of their position and the symbols of their former eminence until the very end. ${ }^{27}$

Truly elite slaves were a tiny minority of th e slave population. A much larger percentage of slaves, however, appear to have concluded that their position as dependents of rich men and their households, though subordinate and ultimately insecure, was preferable to what might await them once freed, when they would have to fend for themselves without protection or attachment. A remarkably recent illustration of this kind of pragmatic calculation comes from the Aden Protectorate as recently as 1943 when a group of royal slaves revolted because they did not wish to be freed. ${ }^{28}$ Violently resisting the ruler's efforts to free them, a move which they interpreted as simply abolishing their privileges, they were finally compulsorily liberated after the ruler summoned the intervention of British Indian troops from Aden. ${ }^{29}$ At other times and in other 
places, slaves might simply exploit the opportunities offered to them by their possession of a small amount of power, delegated to them by their owners, to aggrandize, to the utmost extent, their own positions. ${ }^{30}$

Middle Eastern slavery offered incentives to investment in the system even to those quite low in the slave hierarchy. The hope of manumission, perhaps with gifts or an inheritance, or possession of a mukatebe contract (whereby a slave might purchase his manumission after a fixed number of years or for a fixed sum of money) encouraged cooperation and hard work. Although mukatebe contracts would be much harder for women to obtain, as they rarely worked for wages outside the home, fixed terms for slavery, of perhaps seven or ten years, were often customarily observed for both male and female slaves. Furthermore, those born into slavery, or captured at a young age, would have little accurate knowledge of their origins, and probably nothing to which they might realistically hope to return. Running away was a very risky strategy, impossible for women with children, and marronage communities, of the kind so common in the Americas, were rare.

The meaning of slavery in the Middle East and North Africa was further complicated by another subaltern strategy, the practice of self-enslavement or sale of family members. This was a strategy most commonly found in the enslavement of white Circassian women after the Russian occupation of their lands in the mid-nineteenth century, but was also found among impoverished local people, usually women and children but occasionally men too, at all periods and especially in harsh times. It was a practice which was not confined to Muslims. In Malta, for example, a category of slaves known as the buonavogli continued to exist until abolition in 1802. The buonavogli consisted of men who had sold themselves for life to the galleys of the Order of the Knights of Malta. Such a strategy was inconceivable in the context of Atlantic slavery, and there is no evidence of it having been deployed by Africans in the slaving zones beyond the frontiers of Middle Eastern and North African states. Selfenslavement occasionally offered hope of some social advancement, through for example entering the harem of a rich man and, although such success was probably extremely rare, its possibility may have given the practice some legitimacy and even appeal. ${ }^{31}$ Nonetheless, the willingness of some family members to sell should not be equated with the willingness of women to be sold. Sometimes women cooperated in their own enslavement, and sometimes they did not, and many stories of desperate efforts at escape survive. ${ }^{32}$ The legal ban on the enslavement of Muslims does not seem to have inhibited in practice either the sale, purchase 
or gift of Muslim women and children. In certain circumstances, Muslim men too might offer themselves as slaves, either as a result of desperate poverty or ambition. ${ }^{33}$ The desire to gain access to the privileges believed to be enjoyed by certain categories of slaves might lead to entire communities requesting enslavement be extended to them.

The practical functioning of slavery in the Middle East and North Africa therefore did not give rise to any ideological clarity regarding either the meaning of freedom, let alone equality, or its absolute desirability. The sharp dichotomy between slavery and freedom which theoretically characterizes modernity was not present in the pre-twentieth century Middle East where various forms and degrees of personal dependence were universal. Although in law there was a clear division between free and slave, in social and political reality there was rather a finely graded continuum stretching from one status to the other. ${ }^{34} \mathrm{In}$ law, furthermore, different categories of the population supposedly possessed different capacities and therefore different prerogatives and rights and were subject to different punishments. Certainly slaves were not the legal equals of the free, but neither were women the legal equals of men, nor dhimmis of Muslims. The prevailing norms inevitably constrained both the practical and the ideological options available to slaves. When slaves took action, it was likely to be in search of refuge from abuse, amelioration, perhaps even a 'better' master, rather than in pursuit of an abstract liberty. ${ }^{35}$ There is little evidence of Middle Eastern and North African slaves possessing the ability, individually or collectively, to transcend the ideological limitations of their own immediate environment

The template of American slavery depicts the aim of slave resistance as liberation, absolute legal freedom and individual autonomy as imagined by the politics of liberal democracy and the economics of the free market. Although even here what awaited the free slave was often, in reality, social atomization, marginalization, and economic exploitation, nonetheless the ideal became and remained pristine. In the context of the nineteenth century Middle East and North Africa, the values epitomized by the American slave's flight to freedom were perceived differently. Middle Eastern societies were still predominantly agricultural and urban populations were small, and neither the rural nor the urban areas had experienced the convulsive population movements of an industrial revolution. Here the lone individual, divorced from any broader integrative context, was seen rather as a source of actual and potential threat. Both for society and for the ex-slave, what awaited was marginalization, and consequently criminalization, begging, prostitution, theft, and even banditry. Indeed 
manumission without resources or continuing patronage was a proverbial threat or punishment for a recalcitrant slave. ${ }^{36}$ No American 'flight to freedom' was available in these contexts, on the practical or ideological level. No new cities hostile to slavery, no New York or Chicago, nor any emerging industrial enterprises eager for labour, awaited the freed Middle Eastern slave. Here the uncertainty of life after slavery, the limited opportunities of paid employment, especially for women, the impossibility of a return home, and the difficulties of surviving in an unwelcoming urban world, all militated against slave discontent crystallizing into a generalized rejection of the social order, and often led to many freed slaves accepting a continued connection to their former owner's household, often in a similar role to that which they had occupied while enslaved. Not only the slave, but local elites and the state itself had an interest in this custom, as it avoided any social disruption resulting from the accumulation in urban areas of numbers of the marginal and the destitute, always a source of anxiety and, in the case of freed women, giving rise to a particular fear of rampant immorality.

Nonetheless, the political, legal and ideological shifts of the nineteenth century certainly opened up new possibilities for slave agency. Since the slave condition was usually individual, so too were the remedies pursued, including especially flight or the attempt to obtain legal redress with the newly-available help of local officials or sympathetic European consuls, sometimes these two modes of action coupled together. ${ }^{37}$ During the nineteenth century the incidence of both absconding and slave approaches to courts, and the likelihood of success, seems to have increased dramatically. ${ }^{38}$ Slaves now found themselves not only running away from their masters but with new destinations to which to run. Both the opportunity for escape and the actual encouragement of flight increased as the European powers, especially the British, allowed their consulates and ships to give sanctuary, possible refuges of which runaway slaves were well aware, and centralizing Middle Eastern governments and their local representatives began to look upon slaves and slave-owners through new eyes. Such forms of newly-empowered slave agency were highly effective in weakening and eventually fatally undermining the institution. Furthermore, the legal changes of the nineteenth century, coupled with the blurring of the categories of slave and African, and the common assumptions of the slave status of blacks, opened up entrepreneurial opportunities unthinkable in the context of American slavery. Ehud Toledano has excavated stories, which appear to have been quite common, of tactical collusion between ex slaves and slave dealers to defraud government compensation and settlement schemes. ${ }^{39}$ 
Such strategies, flight, resort to the courts and so on, appear to have been adopted mainly by black slaves and especially black female slaves. Paradoxically, given her relatively privileged position, the slave least likely to seek, and least likely to obtain, manumission was the female white slave. The white slave was also the least visible. Although recent research has located significant visual evidence of African slaves in the Middle East and North Africa, very few images of white slaves have been located. ${ }^{40}$

The demand among the relatively prosperous for female slaves for domestic and sexual services continued and, perhaps until the mid-nineteenth century, even increased among the nouveau riche keen to mimic the mores of their social superiors. ${ }^{41}$ Debates about the position of such women and their customary role within the household as concubine and mother aroused deep anxieties about the inviolability of the household and the prerogatives of its male head. So highly-charged was this matter that the Ottoman empire, for example, was only able to ban the white slave trade in 1909, half a century after the ending of the African trade. The sensitivity of harem slavery and its capacity to become representative of more general political and religious anxieties is illustrated by the spectacular massacre of a Russian mission in Tehran in 1828, after the head of the mission, the poet and dramatist A. S. Griboyedov, insisted on the surrender to him of two captured Georgian women from the harem of a local notable, these women having converted to Islam and borne their owner children and apparently not themselves wishing to be freed. This episode, which became entangled with widespread Iranian resentment at the humiliating terms of the treaty of Turkomanchai which had ended the recent Russo-Iranian war, resulted in the deaths of Griboyedov himself and forty three members of his mission. ${ }^{42}$

Most of the evidence for slave agency dates from the beginning of greater European intervention in the nineteenth century, and is mainly concerned with black slaves. ${ }^{43}$ Indeed, during the nineteenth century, slavery in the Middle East and North Africa became ever more contextualized within a discourse of colour, slavery increasingly defined as black slavery. Black slaves became an absolute majority among the total slave population in the Middle East and North Africa, all sources of supply other than sub-Saharan Africa now closed, while this new preponderance of black slaves encouraged European anti-slavery campaigners to reproduce the tropes of Atlantic slavery and paternalistic white abolitionism. The assimilation of Middle Eastern and North African to black slavery in the Americas was particularly 
encouraged by the work of European missionaries in the late nineteenth century Sudan who recorded, framed and circulated widely several Dinka slave narratives. ${ }^{44}$

In fact, it was only in the nineteenth century that an essential association between colour, or race, and slavery, of the kind that defined the modern Americas, began to be attributed to the institution in the Middle East and North Africa. In earlier periods, slave raiding and trading had followed the military successes of the states of the region. This had resulted in an almost infinite variety in the ethnic origins and racial types of the enslaved populations. ${ }^{45}$ By the nineteenth century, however, this variety had been superseded by a much more homogenized slave population, consisting of two groups, the larger group was composed of black Africans, mainly women but also some men, as domestics and menials, and a very much smaller number of white Circassian women for elite harems. ${ }^{46}$

But this assimilation of black slavery in the Middle East and North Africa to Atlantic slavery also depended on an assumption, made at the time and subsequently, that attitudes to race in these societies were similar. ${ }^{47}$ Certainly deeply-entrenched beliefs about the superiority of a light skin persisted across the Middle East and North Africa, Islamic racial egalitarianism never strong enough to overcome colour prejudice, and everywhere blackness carried with it associations of slave status. Colour was crucial to the slave experience, conditioning the treatment which a slave might expect to receive, options available for amelioration or escape, and prospects after manumission.Yet, although colour consciousness, even colour prejudice, was endemic, attitudes were not commensurate with the binary divisions prevalent in, for example, the antebellum America South. The subversion of European notions of the natural racial order by Middle Eastern slavery often caused astonishment. In 1768 Olaudah Equiano, a freed black slave from South Carolina, visited Smyrna and expressed astonishment at the way in which white slaves were 'kept under by the Turks, as the negroes are in the West Indies by the white people'. ${ }^{48}$ Indeed, so defining a moment was this for Equiano that for a long time he dreamed of emigrating to the Ottoman empire. In the Middle East, and perhaps especially in North Africa, hierarchies of race and colour were neither absolute, immutable nor impermeable and racial identity was constructed differently. This was in striking contrasting to the 'one drop rule' in the US, a colloquial term hinting at a widespread fear of 'invisible blackness,' which became a principle of racial classification adopted into law by some state legislatures. In North Africa, the descriptions 'white' or black' did not necessarily even denote skin colour. In Morocco, for example, descent was the defining characteristic of 
identity, not racial purity. Consequently sons of Arab or Berber fathers and black slave mothers would define themselves by their lineage, taken from their father, not their skin colour, several Moroccan sultans falling into this category. ${ }^{49}$

The conceptualization of Middle Eastern and North African slavery as typically black has been further confirmed retrospectively by the post-emancipation prospects of former slaves. Freed white slaves from elite households, often with material resources and social connections, seem to have suffered from little social stigma and integrated easily, disappearing as a defined category. Female slaves from elite households, for example, seem to have been in great demand as marriage partners and were often assimilated into the same class as the families that had once owned them. ${ }^{50}$ Freed black slaves, on the other hand, appear to have found integration more difficult. While enslaved they were, especially if women, much more frequently assigned to menial labour than white slaves and they carried their low status with them into their post-emancipation lives. They were also far more numerous than emancipated white slaves. As a consequence emancipated black slaves constructed new communal identities and forged collective cultural practices which gave them a permanence, though not necessarily a visibility, in their host societies. ${ }^{51}$ Recent research, in fractured, post-nationalist environments characterized by a new identity politics, has brought these histories to light. Existing black communities in Iran and Turkey have become newly visible, while creolized religious practices such as Zar cults have found their way into popular entertainment across the entire region from Iran to Morocco, likened to black American music and finding an especial popularity with white audiences. ${ }^{52}$

The power and persistence of an identification of Middle Eastern and North African slavery with the trade in and possession of black slaves by lighter-skinned owners is such that that it now requires a considerable effort of imagination and intellect to conceptualize the opposite equation, a historical reality, of white slaves with owners who were people of colour. This conceptual problem is strikingly illustrated by the case of the Barbary slaves. The numbers of Europeans enslaved by Barbary corsairs, privateers operating out of the North African coast, was very considerable indeed, perhaps up to a million between 1500 and $1800 .{ }^{53}$ As late as the mid-nineteenth century, Ahmad Bey, ruler of Tunis and a pioneer of anti-slavery legislation in the region, was the son of a Sardinian slave-mother. ${ }^{54}$ Yet these enslaved Europeans have been almost completely excised from the history of Middle Eastern and North African slavery while the narratives they produced, along with vast quantities of 
material relating to their cases, letters, petitions, reports and so on, have also been disregarded as a source for the analysis of the operation of the institution. ${ }^{55}$

It is often remarked that gaining access to the experience of slaves in the Middle East and North Africa is particularly difficult because of the absence of such slave narratives, itself a consequence of the absence of an ideology of abolitionism. Here too, it should first be noted, the Atlantic slavery template encourages an unbalanced comparison. It is in relation to slavery in the Americas that captivity narratives have played the most significant role and it is here that first-hand accounts written by slaves or former slaves have been so plentiful and significant. Indeed the existence of perhaps as many as six thousand American captivity narratives makes this case quite unique, the slave societies of ancient Greece and Rome, for example, having left no extant slave narratives. ${ }^{56}$ In the case of slavery in the Americas, the very production of so many texts was a direct result of the abolitionist movement, white abolitionists providing an audience and a market and exercising tutelage over the slave narrators. ${ }^{57}$ One consequence was the emergence of a typical enslaved black plantation field hand who became representative of slave life. The narratives tended to homogenize the slave experience, marginalize the agency of the slave-victim, and showcase the transcendant and redeeming moral character of abolitionism.

The European Barbary slaves did indeed produce captivity narratives but neither the slaves themselves nor their accounts have been integrated into the story of Middle Eastern and North African slavery. This erasure partly arises from the fact that the narratives of the Barbary slaves were indeed the product of an anti-slavery movement but, in this case, one which was external to the region and profoundly hostile. The Barbary narratives were indeed highly ideologically inflected, replete with formulaic denunciations, propaganda designed to confirm and promote existing beliefs not only about the cruelty and tyranny of Muslim societies but also, by contrast, the virtues of the slaves' own Europeans countries. ${ }^{58}$ They found a ready audience and market arising from elite and popular anger at their enslavement and sympathy for their fate at home, fuelled by a public eager for tales of Oriental strangeness and excess, these appetites whetted by the ruling discourses of early colonial and imperial expansion. As a result, the Barbary narratives have become a source of unease, even embarrassment, examples of imperial myth-making rather than authentic testimonies of survivors, tainted by their association with the formulation of an emerging Orientalist discourse and their mobilization in the service of an aggressive 'othering' of the Middle 
East. ${ }^{59}$ Far from contributing to the emergence of an homogenized experience of North African slavery, as black captivity narratives were made to do in North America, they have rather been quarantined and divorced from the wider experience of slavery across the region.

The production and wide circulation of Barbary captivity narratives confirmed European views of the degeneracy and cruelty of Muslim societies and was a harbinger of a stronger discourse pitting Occidental against Oriental. The character of the moral and political outrage which the stories generated is, however, uncomfortable to a modern sensibility in other respects, and impossible to mobilize in a redemptive project. The discourse to which the Barbary narratives contributed excoriated the slavery of Christian Europeans, not slavery as such. This was, after all, a period when Muslim slaves were still kept in the galleys of French, Italian and Spanish ships, and when European countries, Britain, France, Spain and Portugal, were developing Atlantic slavery to unprecedented levels. The very existence of enslaved Europeans was seen as unnatural, disrupting the European correlation between slavery and colour. The Europeans enslaved by the Barbary corsairs were irrefutably western, Catholic and Protestant, Italian, French, Spanish, British and even American, unlike the doubtfully European Balkan Orthodox enslaved in large numbers by the Ottomans. But the changing balance of power between the early modern West and the Islamic world made the enslavement of such western Europeans appear, both at the time and subsequently, as an anomalous affront. Indeed, the simultaneous expansion and racialization of Atlantic slavery may itself have heightened this sense of outrage.

The experiences of the Barbary slaves has, accordingly, been confined within a certain uniqueness or exceptionalism, deemed irrelevant to the experiences of slaves in general, especially those of their fellow black slaves, the exoticism which surrounded them making their stories impossible to incorporate into a meta-narrative of the Middle Eastern and North African slavery. Barbary captivity narratives were capable neither of representing the slave experience in general, nor of contributing to a redemptive project within the region or outside it.

The weakness of an abolitionist sentiment across the Middle East and North Africa has often been noted and explained by reference to the power of conservative Islamic prescriptions. Abolitionism has typically been conceptualized as an elite ideology and evidence for its existence sought primarily in textual production, including, in the case of the Middle East and 
North Africa, legislation by rulers, fatwas from members of the ulama, and intellectual or cultural contributions from an intelligentsia familiar with European discourses of modernity. Popular attitudes towards slavery have, on the other hand, attracted little interest and little is understood about how the free, non slave-owning, lower classes across the Middle East and North Africa viewed slaves and slavery. What evidence is there by which to assess popular attitudes? In general, slave holding was confined to a tiny elite. Most families did not own slaves, and this must have included many who had the means and, even when markets were glutted and slaves were cheap, most men seemed to have preferred a free wife to the purchase of a slave concubine. ${ }^{60}$ Enslavement was widely perceived to be a terrible fate, the prospect producing a general revulsion, and slavery a dismal condition. The intermingling of slaves, ex-slaves and the free poor was considerable. Most slaves lived everyday lives that were barely distinguishable from those of the free poor amongst whom they lived. The free and the slave worked side by side, even in the harshest occupations such as that of galley oarsmen, and domestic slaves were an unexceptional element of local societies. The very frequency of manumission, and the variety of strategies available for obtaining it, means that many of the free poor must have had slave connections.

More than this, the free poor joined enthusiastically in the public celebrations of black slaves and ex-slaves. African festivals and carnivals took place in many towns and cities, most famously in Istanbul and Izmir, where they were immensely popular with the local population, especially the young, for whom they provided a temporary space where everyday restrictions were lifted. ${ }^{61}$ Such festivals bore clear resemblances to similar practices among slaves and the lower classes across many historical and geographical contexts, including ancient Rome, early modern Europe and the New World. In the Middle East and North Africa, as elsewhere, these events seem to have offered the wider subaltern society a moment of collective liberation and a powerful symbolic inversion of the existing and oppressive social hierarchy. ${ }^{62}$

But it it possible to go further and find among the Middle Eastern poor that sympathy for maltreated slaves and readiness to act in their defence which is evidenced among, for example, the urban plebs of ancient Rome? ${ }^{63}$ There was indeed in the urban Middle East and North Africa the same daily intermingling between slave and free populations, in work and social life, some at least of the free being descendants of slaves themselves, which produced a certain community of interest in ancient Rome. The plebeian riots of ancient Rome were 
aimed not at slavery as an institution, but at defending particular slaves from the vengeance of their masters. Similar sympathy and even active intervention to protect slaves may indeed be found among the local populations of the Middle East and North Africa. In Cairo in the 1870s, six freed Sudanese slaves were kidnapped and smuggled across the Sinai desert to Nablus to be sold. The kidnapped women apparently felt sufficiently sure of a sympathetic response to knock on a stranger's door in a Palestinian village in search of help. They were not disappointed, the woman of the house hastening to inform the authorities. ${ }^{64}$ The case of the Circassian slave woman named Shemsigul, told by Ehud Toledano, also shows the sympathetic intervention of a compassionate neighbour, a peasant woman, who saved the abused Shemsigul and arranged a safe lodging for her. ${ }^{65}$ At the very least, public opinion seems to have acted as a brake on excessively harsh treatment and perhaps indicates a wider subaltern unease at the total power symbolized by the slave ownership similar to that shown by the British lower classes towards plantation owners in the Americas.

Occasionally, a comprehension of a common interest, or at least a common enemy, seems to have produced an active solidarity between slaves and the free poor, and the latter would flock to resistance mounted by exasperated slaves. The ranks of the Zanj rebels, for example, were swollen by impoverished peasants. Indeed, the peasants of the region appeared to have possessed a general inclination to join the Zanj, probably the result of a degree of black and white class solidarity directed against their common enemies, the owners of the large estates. The ranks of the Zanj were further reinforced by other subaltern elements, runaway slaves, including white slaves, from elsewhere, poor artisans, beduin and black deserters from the Abbasid army. ${ }^{66}$ The nineteenth century provides many, if less spectacular, examples of collaboration between slaves, ex-slaves and the free poor. Fugitives from Egyptian conscription took refuge on slave-run estates and slave bandits operated always in association with free people in remote areas of rural Morocco. In Iran, riots were sometimes led by slaves and slaves seem to have joined bands of lutis, local toughs who sometimes acted in defence of the interests of the poor. ${ }^{67}$

One crucial difference between Atlantic slavery and slavery in the Middle East and North Africa conditioned subaltern attitudes. Unlike Atlantic slavery, slavery in the Middle East was not quarantined within ethnocentric boundaries nor confined to distant colonies. It was rather an ever present threat to those falling to the depths or the margins of society. ${ }^{68}$ The poor of the Middle East and North Africa, especially in the more remote rural areas, were 
themselves at constant risk of enslavement, doctrinal opposition to the enslavement of Muslims notwithstanding, and this fact contributed crucially to the emergence of popular dislike of the institution.

Popular abolitionism therefore, when a wider revolutionary context enabled it to appear, emerged not primarily as a moral issue but rather as a matter of pressing political urgency. The clearest example of this phenomenon of popular abolitionism comes from Iran, where opposition formulated itself in terms of the enslavement of 'us', Muslim Iranians, not the enslavement of 'other,' black Africans. As the story of the 'Daughters of Quchan' shows, by the time of the revolutionary upheavals in early twentieth century Iran, slavery, whether through kidnapping by tribal raiders or sale by destitute families, had become emblematic of the injustice of the rich, the tyranny of rulers and the harshness of peasant life, and had been made into a central mobilizing motif in the struggle for constitutionalism and national independence. ${ }^{69}$ In this narrative of slavery and abolition, Iranians were victims, not perpetrators, and protection, justice and restitution, if not formal abolition, were demanded from the new constitutional authorities.

Subaltern suspicion of slavery and slave owners deserves further research. Elite abolitionism, its significance and even existence, has attracted more attention and has been the subject of some disagreement. The late eighteenth and early nineteenth centuries saw abolitionism occupy a position of central political, economic and especially moral significance in Europe and the Americas, and the apparent reluctance of Middle Eastern elites to follow the same path has aroused unease on one hand and apologetics on the other. The weakness of abolitionism has mainly been attributed, both at the time and subsequently, to the unchallengeable authority of Islam and the relative mildness of the local practice, a relative mildness emphasized by comparisons to American slavery. ${ }^{70}$ As Bernard Lewis most famously stated: 'The abolition of slavery itself would hardly have been possible. From a Muslim point of view, to forbid what God permits is almost as great an offense as to permit what God forbids - and slavery was authorized and regulated by the holy law. ${ }^{71}$ This view, adopted by both Europeans and diplomats, anti-slavery activists and missionaries and also of their antagonists defending the practice, first emerged in the nineteenth century and has since shown a surprising resilience, trapping discussion about slavery in the Middle East and North Africa within an Orientalist hall of mirrors. ${ }^{72}$ 
Although it remained far from hegemonic, an elite critique of slavery did develop in the nineteenth century Middle East, both among secular and religious reformers and modernists. It was, however, complicated by the needs of rulers to protect their sovereignty from imperial diktat and the desire of an emerging intelligentsia to defend the cultural integrity of their societies. The British presentation of their anti slave-trade measures in terms of moral superiority provoked a defensive reaction from those in the region who feared further intervention by stealth and perceived a disguised but generalized attack on their religion and culture. They responded by contrasting local slavery favourably with that of the Americas, stressing the domestic character of local practice and the benign treatment which slaves might expect.

The model of plantation slavery in the Americas has thus been used, both in the nineteenth century and subsequently, to measure Middle Eastern slavery. Each side in the debate has mobilized one particular variety of the slave experience, those who emphasized the variety and mildness of the slave experience in the Middle East focusing on white harem slavery, their opponents drawing comparisons between the trans-Saharan trade in Africans and the 'Middle Passage' of Atlantic slavery, stressing similarities in terms of the trauma of violent capture, transport across vast territories, sale and total powerlessness, each stage accompanied by high rates of mortality. ${ }^{73}$ This 'better or not' debate, however, takes place outside of the slaves' own experience and its attempts to locate forms of slavery arising in completely different historical circumstances on a scale of brutality sheds little light on the slaves' appreciation of their own situation. In this sense, what was of relevance to both black and white slaves in the Middle East and North Africa was not the lives of slaves thousands of miles away, of whose existence they were certainly unaware, but rather how they judged their own enslavement in terms of the possible alternatives available to people such as themselves.

In the 'better or not' argument, especially as it refers of black slaves, the American model is crucial. In relation to the question of abolitionism, the American and European experience is again central, although usually only in moral, and rarely in comparative historical, terms. The evolution of the nineteenth century Ottoman discourse on slavery among statesmen, reformers and literary figures has been traced in detail, and its inadequacies, its hesitations, its ambiguities and its contradictions documented. ${ }^{74}$ The Western abolitionism against which this discourse is contrasted is, however, left largely unproblematized. Indeed it is an 
exculpating self-image of Western elite abolitionism which is first constructed and then deployed as the norm against which Middle Eastern or 'Islamic' exceptionalism is judged.

It should, however, be noted that in Europe domestic slavery ended without the development of any mass abolitionist sentiment. In Spain, for example, slavery simply withered away without any legislation, in Portugal slavery was ended by the Marquis of Pombal in 1761 in the heyday of enlightened absolutism, in Malta abolition had to await the arrival of Napoleon. Even regarding colonial slavery, opposition originally arose among circles far from power, such as among British Quakers and other non-conformist radicals, themselves subject to severe disabilities, and it was only after lengthy and bitterly contested struggles that notions of slave emancipation made headway on elite and official levels. Even during the high point of the emancipation campaign, elite attitudes in Europe remained ambiguous. Revolutionary France abolished slavery in 1794, only for it to be re-established by Napoleon in 1802, and in 1840s Algeria the French colonial authorities even pondered plans to purchase thousands of sub-Saharan slaves to provide labour and military service and even, in light of the failure to crush Algerian resistance, to use them to displace and replace the existing Arab and Berber population. ${ }^{75}$

In fact, it is possible to locate one, but only one, episode of coherent, sustained and successful popular abolitionism. Like the form of slavery itself, late eighteenth/early nineteenth century Western abolitionism was historically unique. Slave revolt aimed as abolishing slavery, a feature of the same period, was also unique. By contrast, as typically shown by the Zanj revolt, one of the first acts of rebellious slaves was often to take slaves themselves. Prior to the last quarter of the eighteenth century, all societies accepted slavery as a legitimate social institution, elite discourses, both religious and secular, providing legitimacy and even encouragement. Neither classical Greece nor Rome, nor medieval or early modern Europe was ill at ease with slavery. Nor was Europe's ideological embrace of the practice disturbed by the unprecedented expansion and super-exploitation of the modern plantation system. This system, as it shattered older notions of slavery, also led to the generation of quite novel justifications to match the new circumstances.

The destruction of slavery in the Americas was only partly a result of a new middle class abolitionism which read the Bible in a new way. This abolitionism, itself a product of rapidly changing circumstances, required, for its triumph against elite resistance, vast and profound 
political, social and economic transformations in both the slave colonies and the metropolitan countries. These transformations were driven by epochal political events, the French, American and Spanish American revolutions, by corresponding ideological changes such as the emergence of radical democratic ideas and natural rights and 'the rights of man,' and notions of the superiority of free labour, and economic developments, especially British industrialization and accompanying rise of a middle and a working class, both contributing to the formation of a public opinion and eager to assert themselves.

Most of all, however, the abolition of slavery in the Americas required slave agency, including crucially collective manifestations of violence, endemic resistance taking myriad forms and finally culminating in the Haitian revolution of the1790s, Black Jacobins politicizing rebellion until it could aim at general emancipation and achieving an unprecented victory, the first slave revolt to overthrow a slave society. ${ }^{76}$ The history of plantation slavery in the Americas is coterminous with the history of slave rebellion and its bloody suppression. Slave revolts in the Caribbean, for example, were regular events, made more fearsome by the huge disparity in numbers between slaves and their owners. In the French and British sugar islands for example, slaves comprised eighty to ninety per cent of the population. Although slave rebellion was not sufficient in itself for the rise of an abolitionist movement, it was certainly necessary. The final destruction of slavery in the Americas was the result of its becoming politically untenable, condemned by the nexus of accumulated connections between 'slave rebels and anti-slavery radicals, metropolitan abolitionism and wider democratic upheavals. ${ }^{, 77}$

The tensions which exploded across Europe and the Americas in the late eighteenth and early nineteenth centuries were experienced in the Middle East and North Africa largely in terms of an immensely more aggressive imperialism. Neither the political nor the economic developments which took place in Europe and the Americas had contemporary parallels in the Middle East. Elite agendas of political reform remained authoritarian, their discourse little challenged by any subaltern radicalism, and no slave colonies generated super-profits to kickstart an industrial revolution and its accompanying class struggles. Only a century later, when slavery had already waned, did radical and democratic ideas begin to offer a serious threat to the established order and its elites. Most importantly, and in starkest contrast to the Americas, Middle Eastern slaves offered no organized or political threat either to individual masters, to the slave-holding elite, or to the state. Abuse and desperation might produce individual slave 
violence, up to and including arson and murder. Even here however, the threat it represented was reduced by the fact that most offenders were women, unsurprising given the emotional and psychological tensions of households characterized by polygamy and concubinage. ${ }^{78}$ The societies of the Middle East and North Africa, lacking any tradition of armed slave revolts, seem to have harboured fewer fears of slave violence, presenting a stark contrast to the societies of ancient Greece and Rome or the modern Americas, which were pervaded by such fear. No anxieties of slave resistance pervaded Middle Eastern societies nor haunted elite reformers. In contrast to Atlantic slavery, Middle Eastern slaves were imported not into colonies but into the imperial heartlands, including capital cities such as Istanbul, Cairo and Tehran. But in these environments they remained a small minority of the total population. With the exception of the medieval Zanj revolt, they never offered, were never in a position to offer, any challenge either to the institution of slavery or to the system in which it was embedded. Seeing slaves as constituting no danger or threat, Middle Eastern elites felt under no urgent compulsion to address their plight. Such compulsion came rather from European imperial pressure, its impact was ambiguous and it was resisted accordingly.

Nonetheless, during the nineteenth century, slavery across the Middle East and North Africa was progressively restricted by state action and, as in Britain, initial efforts were aimed at suppressing the slave trade rather than abolishing slavery or emancipating existing slaves. A first bold initiative came in 1841 when the Bey of Tunis prohibited both slavery and the slave trade. In 1846 Istanbul's central slave market was closed. In 1848 the shah of Iran issued a farman prohibiting the trade in the Persian Gulf. ${ }^{79}$ In 1857 Ottomans banned the African slave trade. 1877 and1880 saw respectively Anglo-Egyptian and Anglo-Ottoman Conventions for the suppression of the slave trade and in 1890 the Ottoman empire became a signatory to the international Brussels Act forbidding the African trade. In 1909 the Committee of Union and Progressed prohibited the Circassian slave trade.

The template of modern Atlantic slavery has encouraged a tendency to see an open ideological commitment to abolitionism within the slave owning societies as crucial to the suppression of the institution. Yet, across the Middle East and North Africa, although no hegemonic abolitionist sentiment emerged, yet the nineteenth century saw a profound change in the politics of slavery, specifically the ways in which states such as the Ottoman empire, Egypt and Tunisia, at both central and local levels, dealt with slaves. This was certainly partly a product of constant European pressure, but it was also a result of an internal dynamic of 
modern state-building. ${ }^{80}$ Such change is particularly evident in the response of the courts. ${ }^{81}$ Hitherto the state, the courts and the ulama had all lent their weight to upholding the prerogatives of slave-owners, only freeing abused slaves in the most extreme cases, and otherwise assisting in the recapture of runaways and permitting their punishment by their owners. However, as modernizing, centralizing, secularizing elites extended their reach, they enabled the state to take over the management of slavery, gradually removing it from the ambit of the shariah, and increasingly intervening in the hitherto private realm of the slave owner's household. By the end of the nineteenth century, the Ottoman state had leant decisively away from defending slave-owners' rights towards favouring the runaway slave. Running away almost invariably ended in successful manumission and was becoming recognized as a legitimate way of obtaining liberation. ${ }^{82}$ Egypt underwent a similar process. Here too, the owner's control of his or her slave was undermined by successive state interventions, including the establishment of manumission bureaux, to the point where ownership became a legal fiction. In 1881 the Cairo manumission bureau was instructed by the minister of the interior to issue manumission certificates to all applicants regardless of circumstances and by the mid-1880s it appeared that any slave who desired manumission was able to obtain it. ${ }^{83}$ Slaves were now able to make decisions regarding their work, marriage partner and place of residence and, as a last resort, simply to leave their owners.

These political and legal changes cumulatively transformed the relationship between slave and slave-owner and the perceptions of both by the wider society. At the same time, transformations in the nature of society, specifically the decline of the extended, polygamous aristocratic household, augured the end of the old order for both owner and slave. In contrast to the Americas, almost no one came to slavery's defence. By the end of the nineteenth century, slavery in the Middle East and North Africa, although still awaiting formal abolition, had become unenforceable. It finally disintegrated from below, slaves taking matters into their own hands and voting with their feet, simply walking away from their owners who now lacked both the desire and the coercive mechanisms to retain them. 
The author is grateful to Roshan Cultural Heritage Institute and its President, Dr Elahé Omidyar Mir-Djalali, for funding the fellowship which enabled her to work on this article.

1 A good example of this dominance is provided by James Walvin, A Short History of Slavery (London: Penguin, 2007). Of the book's 235 pages, only the first 34 deal with slavery outside the Americas.

2 For an early critique of the notion of the redemptive character of abolitionism, see Eric Williams, Capitalism and Slavery (Chapel Hill: University Of North Carolina Press, 1944).

3 The notion of a uniquely religiously-defined, 'Islamic' slavery is surprisingly tenacious. See, for example, the organization of the annual bibliographies provided by the leading journal in the field of slavery studies, Slavery and Abolition. The bibliographies are organized by geographical area and theme, with the exception of the one religious/civilizational category,'Muslim slavery'. Thomas Thurston, 'Annual Bibliographical Supplement (2013)'. Slavery and Abolition, vol. 35, no. 4, 2014, 681781. Suzanne Miers, 'Slavery and the slave trade in Saudi Arabia and the Arab states on the Persian Gulf, 1921-1963', Gwyn Campbell (ed), Abolition and its Aftermath in Indian Ocean Africa and Asia (Milton Park, Abingdon: Routledge, 2005), p. 128. See the remarks of Chouki El Hamel, Black Morocco: A History of Slavery, Race and Islam (Cambridge: Cambridge University Press, 2013), p. 1. Mohammed Ennaji, Slavery, the State and Islam (Cambridge: Cambridge University Press, 2013).

7 Robin Blackburn, The Overthrow of Colonial Slavery, 1776-1848 (London: Verso, 1998), p. 41.

$8 \quad$ Blackburn, The Overthrow of Colonial Slavery, p. 18.

$9 \quad$ For the cental role of slave soldiers see, for example, Christopher Leslie Brown and Phillip D. Morgan (eds), Arming Slaves: From Classical Times to the Modern World (New Haven: Yale University Press, 2006); Daniel Pipes, Slave Soldiers and Islam: The Genesis of a Military System (New Haven: Yale University Press, 1980). See especially Ehud R. Toledano, As If Silent and Absent: Bonds of Enslavement in the Islamic Middle East (New Haven (Conn.) : Yale University Press 2007); Eve M. Troutt Powell, Tell This in My Memory: Stories of Enslavement from Egypt, Sudan and the Ottoman Empire (Stanford: Stanford University Press, 2012); Terence Walz and Kenneth M. Cuno (eds), Race and Slavery in the Middle East: Histories of TransSaharan Africans in Nineteenth-Century Egypt, Sudan, and the Ottoman Mediterranean (Cairo; New York : American University in Cairo Press, 2010); Anthony A. Lee, 'Enslaved African Women in Nineteenth-Century Iran: The Life of Fezzeh Khanom of Shiraz', Iranian Studies, vol. 45, no. 3, May 2012; Martin, The Qajar Pact: Bargaining, Protest and the State in Nineteenth-Century Persia (London: I. B. Tauris, 2005), ch. 9. See for example, Fuad Matthew Carswell, The Slave Girls of Baghdad: the Qiyān in the Early Abbasid Era (London: I. B. Tauris, 2011). For a discussion of the advantages and disadvantages to women of the manipulation of their sexuality see See Madeline C. Zilfi, Women and Slavery in the Late Ottoman Empire (Cambridge: Cambridge University Press, 2010), pp. 153-188. Zilfi, Women and Slavery. 
See El Hamel, Black Morocco, pp. 12, 297; Christina Proenza-Coles, Encyclopedia of African American History, Leslie Alexander and Walter Rucker, eds. ABC-CLIO, 2008, http://christinaproenza.org/SietePartidas.html Robin Blackburn, The American Crucible: Slavery, Emancipation and Human Rights (London: Verso, 2011), p. 13. See El-Hamel, Black Morocco, pp. 62-77. A. C de C. M. Saunders, A Social History of Black Slaves and Freedmen in Portugal, 1441-1555 (Cambridge: Cambridge University Press, 1982). See El-Hamel, Black Morocco. Meyers, 'Class, Ethnicity, and Slavery: The Origins of the Moroccan 'Abid', The International Journal of African Historical Studies, vol. 10, no. 3, pp. 427-442. El-Hamel, Black Morocco.

William Gervase Clarence Smith, Islam and the Abolition of Slavery (Oxford: Oxford University Press, 2006) pp. 38-9; Y. Hakan Erdem, Slavery in the Ottoman Empire and its Demise, 1800-1909 (Basingstoke: Palgrave, 1996), pp. 1-11.

The Ottoman empire provides yet another example of blatant disregard of Islamic precepts on slavery in its reliance on the 'domestic manufacture' of slave eunuchs, a practice expressly and unambiguously forbidden by law. See A. Ezgi Dikici, 'The Making of Ottoman Court Eunuchs: Origins, Recruitment Paths, Family Ties, and "Domestic Production”, ', Archivum Ottomanicum, vol. 30, 2013, p. 131. Although Muslims might use, buy and sell eunuchs legitimately, the act of castration itself was supposed to be confined to regions outside the realm of Islam.

The account of the Zanj revolt given here is drawn from mainly from Alexandre Popovic, The Revolt of African Slaves in Iraq in the 3rd/9th Century (Princeton, N.J. : Markus Wiener Publishers, 1999) and 'The Zandj_ revolts in 'Irāk', Encyclopaedia of Islam, second edition (Leiden, 2002). See also L. Massignon, 'Zandj', Encyclopaedia of Islam, first edition (Leiden, 1987); Dionisius A. Agius, 'A selfish pursuit in a slave uprising of third/ninth century Iraq', Slavery and Abolition, vo. 4, no. 1, 2008, pp. 318; Ghada Hashem Talhami, 'The Zanj Rebellion Reconsidered', The International Journal of African Historical Studies, vol. 10, no. 3, 1977, p. 443-461; Bernard Lewis, The Arabs in History (London: Hutchinson University Library, 1960), pp. 103-6, and Perry Anderson, Lineages of the Absolutist State (London: New left Books, 1974), pp. 367n, 501n, 509. Massignon, 'Zandj',; Agius, 'A selfish pursuit', p. 10. Popovic, 'The Zandj_revolts in 'Irāk', Encyclopaedia of Islam. Popovic, 'The Zandj revolts in 'Irāk', Encyclopaedia of Islam; The Revolt of African Slaves, p. 154. Sources about the Zanj revolt are few, elliptical and ambiguous. Nonetheless, the episode has been adopted as an early Middle Eastern example of a class war and and likened to the revolts of Spartacus and Toussaint Louverture. See for example, L. Massignon, 'Zandj'; Popovic, The Revolt of African Slaves, p. 2. Zilfi, Women and Slavery, pp. 136, 141. For an official Ottoman register from 1903 comprising the biographies of 194 black eunuchs at court see Ehud R. Toledano, 'The Imperial Eunuchs of Istanbul: From Africa to the Heart of Islam', Middle Eastern Studies, vol. 20, no. 3, 1984. For a biography see Jane Hathaway, Beshir Agha: Chief Eunuch of the Ottoman Imperial Harem (London: Oneworld, 2005). For their wealth see, inter alia, Jane Hathaway, 'The Wealth and Influence of an Exiled Ottoman Eunuch in Egypt The Waqf Inventory of 'Abbas Agha', Journal of the Economic and Social History of the Orient, vol. 37, no. 4, 1994 
See Hakan Erdem, Slavery in the Ottoman Empire, pp. 149-50 for the humiliation imposed on the Ottoman Head Eunuch by the Committee of Union and Progress and the eunuch's pathetic attempts to maintain his prestige and his role.

The account of this episode given here is taken from Suzanne Miers, 'Slave Rebellion and Resistance in the Aden Protectorate in the Mid-Twentieth Century,' Edward Alpers, Gwyn Campbell and Michael Salman, Slavery and Resistance in Africa and Asia (Abingdon: Routledge, 2005), pp. 99-108.

Miers, 'Slave Rebellion'.

Ehud R. Toledano, As If Silent and Absent, pp. 198-200.

Hakan Erdem, Slavery in the Ottoman Empire, pp. 49-51.

Zilfi, Women and Slavery, p. 212; see also the stories collected by Ehud Toledano, As If Silent and Absent.

Mohammed Ennaji, Serving the Master: Slavery and Society in Nineteenth-Century Morocco, trans. Seth Graebner (Basingstoke : Macmillan, 1999), p. 89.

Ennaji, Serving the Master, p. 89.

Dennis D. Cordell, 'No liberty, not much equality, and very little fraternity: The mirage of manumission in the Algerian Sahara in the second half of the nineteenth century', Slavery and Abolition, vol. 19, no. 2, 1998. p. 46.

Martin, The Qajar Pact, p. 156.

Toledano, As If Silent and Absent.

For the use of the courts by slaves in an earlier period see Yvonne Seng, 'A Liminal State: Slavery in Sixteenth-Century Istanbul', Shaun E. Marmon (ed) Slavery in the Islamic Middle East (Princeton: Markus Wiener Publishers, 1999), pp. 25-42.

Toledano, As If Silent and Absent, p. 76-78

See, for example, Pedram Khosronejad, The face of African slavery in Qajar Iran - in pictures, http://www.theguardian.com/world/iran-blog/2016/jan/14/african-slavery-inqajar-iran-in-photos?CMP=oth_b-aplnews_d-2

A number of memoirs of harem life which discuss the place of slaves have been composed by elite women of the Ottoman empire, Egypt and Iran. See, for example, Huda Sha'rawi, Harem Years: The Memoirs of an Egyptian Feminist, 1879-1924 (trans., ed., intr. Margot Badran) (London: Virago, 1986); Taj al-Saltanah, Crowning Anguish: Memoirs of a Persian Princes from the Harem to Modernity, 1884-1914 (ed. and intro. Abbas Amanat, trans. Anna Vanan, Amin Neshati), (Washington D.C.: Mage Publishers, 1993); Leyla (Saz) Hanımefendi, The Imperial Harem of the Sultans: Daily Life at the Çirağan Palace during the 19th Century, translated by Landon Thomas (Istanbul: Peva Publications, 1994).

Laurence Kelly, Diplomacy and Murder in Tehran: Alexander Griboyedov and Imperial Russia's Mission to the Shah of Persia (London: I. B. Tauris, 2002). Toledano, As If Silent and Absent; Troutt Powell, Tell this in My Memory; Walz and Cuno (eds), Race and Slavery in the Middle East; John Hunwick and Eve Troutt Powell (eds), The African Diaspora in the Mediterranean Lands of Islam (Princeton NJ : Markus Wiener Publishers, 2002); Ehud R. Toledano, African Communities in Asia and the Mediterranean: Identities between Integration and Conflict (London, Trenton, NJ : Africa World Press, 2011); Rita Aouad, 'Slavery and the situation of blacks in Morocco in the first half of the twentieth century', Driss Maghraoui (ed), Revisiting the Colonial Past in Morocco (Milton Park, Abingdon: Routledge, 2013). Troutt Powell, 'How Salim C. Wilson Wrote His Own Enslavement', Tell this in My Memory, pp. 80, 83. Zilfi, Women and Slavery, p.104. 
Zilfi, Women and Slavery, p.104.

Perhaps the fullest discussion of colour and race may be found in El Hamel, Black Morocco. See also Murat Ergin, ' 'Is the Turk a White Man?' Towards Theoretical Framework for Race in the Making of Turkishness', Middle Eastern Studies, vol. 44, no. 6, 2008.

Quoted in Linda Colley, Captives (New York: Anchor, 2002), p. 119. See Olaudah Equiano, The Interesting Narrative of the Life of Olaudah Equiano or Gustavus Vassa, the African (ed Angelo Constanzo) (Peterborough, Ont.: Broadview Press, 2001).

El Hamel, Black Morocco, p. 96.

Tucker, Women in nineteenth-century Egypt (Cambridge: Cambridge University Press, 1985), p 188.

The difference between presence and visibility is discussed by Tamar Herzog, 'How

Did Early-Modern Slaves in Spain Disappear? The Antecedents', Republics of

Letters: A Journal for the Study of Knowledge, Politics, and the Arts, vo. 3, no. 1, 15

September 2012, http://rofl.stanford.edu/node/106.

For groundbreaking work on surviving black communities, descendants of slaves, see

Alexander Lopashich, 'A Negro Community in Yuoslavia', Man, vol.58, 1958;

Ahmad Alawad Sikainga, Slaves into Workers: Emancipation and Labor in Colonial

Sudan (Austin Tx: University of Texas Press, 1996); Esma Durugönül, 'The

Invisibility of Turks of African Origin and the Construction of Turkish Culural Identitiy: The Need for a New Historiography', Journal of Black Studies, vol. 33, no. 3, 2003; Behnaz A. Mirzai, 'African Presence in Iran: Identity and its Reconstruction in the $19^{\text {th }}$ and $20^{\text {th }}$ centuries', Revue Française D'Histoire $d^{\prime}$ 'Outre-Mer, vol. 89, nos. 336-7, 2002. Behnaz Mirzai has also made two documentary films, Afro-Iranian Lives and The African-Baluchi Trance Dance. For ex-slaves self-help organizations see Hakan Erdem, Slavery in the Ottoman Empire, pp. 173-6; Toledano, As If Silent and Absent, p. 209-11. For the popularity of the music of former slaves see el-Hamel's discusson of the Moroccan Gnawa, Black Morocco, pp. 270-96, and also Richard C. Jankowsky, Stambeli: Music, Trance, and Alterity in Tunisia (Chicago: University of Chicago Press, 2010)

See, inter alia, Robert C. Davis, Christian Slaves, Muslim Masters: White Slavery in the Mediterranean, the Barbary Coast, and Italy, 1500-1800 (London: Palgrave Macmillan, 2003); Daniel J. Vitkus (ed), Introduced by Nabil Matar, Piracy, Slavery and Redemption: Barbary Captivity Narratives from Early Modern England (New York: Columbia University Press, 2001); Ellen G. Freidman, Spanish Captives in North Africa in the Early Modern Age (Madison, Wis., University of Wisconsin Press, 1983); Linda Colley, Captives, pp. 99-134.

Ismael Musah Montana, The Abolition of Slavery in Ottoman Tunisia (Gainesville, University Press of Florida, 2013), p. 2.

For one of the few women to write and publish a full-length Barbary narrative, see Linda Colley, The Ordeal of Elizabeth Marsh (London: Pamtheon Books, 2007). Two other narratives purportedly written by women are almost certainly fictional. See Paul Baepler (ed and introduction), White Slaves, African Masters: An Anthology of American Barbary Captivity Narratives (Chicago: University of Chicago Press, 1999).

M. I. Finley, Ancient Slavery and Modern Ideology (London: Penguin, 1980). p. 108

Eve M. Troutt Powell, 'Will That Subaltern Ever Speak? Finding African Slaves in the Historiography of the Middle East', Israel Gershoni, Amy Singer, Y. Hakan 
Erdem (eds), Middle East Historiographies: Narrating the Twentieth Century (Seattle, University of Washington Press, 2006), p. 245.

Colley, Captives, p. 101; Vitkus and Matar, Piracy, Slavery and Redemption, p. 34.

See also Joe Snader, Caught Between Worlds: British Captivity Narratives in Fact and Fiction (Lexington, University Press of Kentucky, 2000).

The slave narratives recorded by missionaries in the nineteenth century Sudan have been similarly deconstructed. See, for example, Eve M. Troutt Powell, 'How Salim C. Wilson Wrote His Own Enslavement', pp. 77-113.

Zilfi, Women and Slavery, pp. 142, 146. The situation in Egypt, where possession of a least one black slave seems to have been quite widespread, seems exceptional. See Gabriel Baer, 'Slavery and Its Abolition', Studies in the Social History of Modern Egypt (Chicago: University of Chicago Press, 1969). Khartoum is another unusual case. See Ahmad Alawad Sikainga, 'Slavery and Social Life in Nineteenth-Century Turco-Egyptian Khartoum', Walz and Cuno (eds), Race and Slavery, p.153. Y. Hakan Erdem, Slavery in the Ottoman Empire, p. 174; Toledano, As If Silent and Absent, p. 209-11. Toledano, As If Silent and Absent, p. 211.

Liat Kozma, 'Black, Kinless, and Hungry: Manumitted Female Slaves in Khedivial Egypt', Walz and Cuno (eds), Race and Slavery, p. 197.

Ehud R. Toledano, 'Shemsigul: A Circassian Slave in Mid-Nineteenth-Century Cairo', Edmund Burke 111 and David N. Yacoubian, Struggle and Survival in the Modern Middle East (Berkeley: University of California Press, 2006).

Agius ,'A selfish pursuit,' pp. 10-11. Ghada Hashem Talhami, ‘The Zanj Rebellion Reconsidered', The International Journal of African Historical Studies, vol. 10, no. 3, 1977, p. 445.

Martin, The Qajar Pact, p. 157.

See Suraiya Faroqui, 'Trying to Avoid Enslavement: The Adventures of an Iranian Subject in Eighteenth-Century Anatolia', Another Mirror for Princes: The public image of the Ottoman sultans and its reception (Istanbul, 2008), pp. 219-232. Afsaneh Najmabadi, The Story of the Daughters of Quchan: Gender and National Memory in Iranian History (New York: Syracuse University Press, 1998). Ehud R. Toledano, Slavery and Abolition in the Ottoman Middle East (Seattle: University of Washington Press, 1998), p. 127.

Bernard Lewis, Race and Slavery in the Middle East (New York: Oxford University Press, 1990), p. 78.

Notions of the weakness of Muslim abolitionism, and the immutable and defining primacy of Islamic texts, have recently been comprehensively critiqued. See Clarence Smith, Islam and the Abolition of Slavery; El Hamel, Black Morocco. John Wright, The Trans-Saharan Slave Trade (Abingdon: Routledge, 2007). See, for example, Toledano, Slavery and Abolition, p. 112-54.

Benjamin Claude Brower 'Rethinking Abolition in Algeria: Slavery and the 'Indigenous Question', Cahiers d'Études Africaine, vol. 49, 2009, pp. 805-827. Blackburn, The Overthrow of Colonial Slavery, p. 527; C. L. R. James, The Black Jacobins (New York, 1938, London: Pemguin, 2001). Blackburn, The Overthrow of Colonial Slavery, p. 531. The exact contribution of slave revolt to abolitionism has been the subject of some controversy. See Seymour Drescher and Pieter C. Emmer (eds), Who Abolished Slavery? Slave Revolts and the 
Abolition of Slavery: A Debate with João Pedro Marquesh (New York: Berghahn Books, 2010). Zilfi, Women and Slavery, p. 174-9. See also Y. Hakan Erdem, 'Magic, Theft and Arson: The Life and Death of an Enslaved African Woman in Ottoman İzmit', Walz and Cuno (eds), Race and Slavery in the Middle East, pp. 125-146.

Behnaz A. Mirzai, 'The 1848 abolitionist farmān: a step towards ending the slave trade in Iran', Gwyn Campbell (ed), Abolition and its Aftermath, pp. 94-102. For a discussion of their interaction in the North African context, see Montana, The Abolition of Slavery in Ottoman Tunisia. Toledano, As If Silent and Absent, p.112.

This process is described in detail by Toledano, As If Silent and Absent. Judith E. Tucker, Women in nineteenth-century Egypt (Cambridge, 1985), p. 177. 